\title{
The Taciturnity of Aeneas
}

AENEAS: Good, good, my lord; the secrets of nature have not more gift in taciturnity.

(Shakespeare, Troilus and Cressida, Act IV scene iii)

Aeneas' speech of defence before Dido (Aen. 4.333-6I) is the longest and most controversial he delivers. Although by no means typical, it can open up some revealing perspectives over the rest of the poem.

The exchange between the two, having as its kernel a dispute over obligations and responsibilities, requires some words of context. The early part of the book describes the establishment of a liaison between the refugee leaders, while revealing amongst the poem's characters a wide discrepancy of opinion over the nature of that liaison. Juno announces that she will arrange the marriage of the couple (I25-7); after the ensuing marriage-parody of the cavescene (165-8), Dido also calls what now exists a 'marriage': coniugium uocat, hoc praetexit nomine culpam ('she calls it a marriage, and gives a protective fringe to her fault with this name', I72). Fama too, moving around Libya, speaks as if Dido has taken Aeneas for a husband (192). But the local King Iarbas regards Aeneas as a pirate who has carried off a successful job of plunder (2I7), while Jupiter looks down from heaven and sees 'lovers', amantis (22I). Mercury is able to address Aeneas as uxorius (266).

Some scholars would have it that there is a genuine ambiguity of fact here. ${ }^{2}$ As they point out, Roman marriage was a matter of cohabitation and

${ }^{\text {I }}$ A first draft of this paper was written while I was a guest at the Fondation Hardt in Geneva, during the summer of I98I; I am very pleased to be able to thank the Fondation for their hospitality, together with the British Academy for the financial assistance that made my stay possible. I also owe a debt of thanks to Professor R.G.M. Nisbet, Professor H.D. Jocelyn and Dr. N.J. Richardson, for their helpful criticisms and comments.

${ }^{2}$ G.W. Williams (1968), 378-83 may fairly be taken as representative; cf. Beaujeu (1954). Monti (I98I), 45-8 goes even further, arguing that there is no ambiguity, and that Aeneas is indubitably married. 
intent: any accompanying ceremonies had no legal status and were, strictly, irrelevant to the inception of the marriage. ${ }^{3}$ Dido, by this view, is quite justified in regarding their liaison as a real marriage: Aeneas is living with her and cooperating with her as consort, in building the new city of Carthage.

There are serious obstacles, however, to believing that Virgil can have intended his audience to regard it as a possibility that this 'marriage' might be an established fact. ${ }^{4}$ Elaborate ceremonies may not have been a legal necessity, but individuals of status and importance lived a public life in which such connections were formally marked and openly advertised. The ancient commentators have it right, when they elaborate upon Aeneas' later denial that a marriage exists between them, showing that for persons of this rank there is more to a marriage than mere cohabitation. Ti. Claudius Donatus paraphrases Aeneas' words thus (on line 339):

iunctus sum, inquit, tibi, sed illud non potest coniugium uocari; non enim semper mulieris ac uiri conuentio matrimonium facit. aliud uocatur quod gessimus. quale enim matrimonium est ubi nullus testis interfuit, nulla ex more sollemnitas, nulla pactio, faces nullae, nulla ipsius foederis consecratio?

I am joined to you, he says, but that cannot be called a marriage; for the coming together of a woman and a man does not always make a wedding. What we have done is called something else. For what kind of wedding is it when there was no witness, no ceremony according to custom, no pledge, no wedding torches, no consecration of the compact itself?5

The ambiguity here is not one of fact-are they really married or not?because in real terms it is plain enough that they are not married. The ambiguity resides in the characters' own interpretation. Aeneas is, by the Roman view, behaving in such a way as to give Dido (and various other characters) some justification for imagining that his intention involves marriage. By directing his focus away from Aeneas until the intervention of Mercury (259-78), Virgil is able to maintain a silence over his hero's own beliefs on this score. ${ }^{6}$

Mercury's message reduces Aeneas to panic. He tells his men to conceal their preparations for departure: he will wait for the right opportunity to inform the Queen (287-94). Dido senses the deception and seeks Aeneas

\footnotetext{
3 Cf., e.g., Balsdon (I962), I8I-2.

4 Objections of various kinds given by Klingner (1967), 443-4; Sparrow (I973), 5-7.

5 On 339: Servius Auctus has similar comments. On the scale and cost of marriage ceremonies in the upper classes, see Friedlaender (I9I9), I.274-5.

${ }^{6}$ For the direction of the narrative away from Aeneas here, see Klingner (1967), 444-6; Grimm (1969).
} 
out. The speech which she then delivers (305-30) is conventionally described as being in the 'high tragic-rhetorical tradition', ${ }^{7}$ the most important paradigms being the speeches of Euripides' and Apollonius' Medea. ${ }^{8}$ Austin feels obliged to assert that 'the strength of Dido's personality towers above all the rhetoric', ${ }^{9}$ but we do not drain her speech of its emotion or individuality if we recognise its rhetorical organisation and impetus. Virgil has given her an ideal rhetorical animus. She has a good case and she argues it all the way and from every side, with rage (305-II), close logic (3II-I3) and appeals to pity (320-30). ${ }^{\mathrm{IO}}$ Above all, two crucial points that admit of some doubt are transformed by her words into plain fact: the nature of his leaving and the nature of their relation to each other. To Dido, there is no question about these matters, he is simply in the wrong. Servius Auctus has the tone of it: hic quasi reus Aeneas a Didone accusatur ('here Aeneas is accused by Dido like a defendant in court', on line 305). ${ }^{\mathrm{II}}$

Aeneas' opening words in reply give the first sign of the distinction between the two in their use of speech, and of Aeneas' recognition of that difference. To begin with pro re pauca loquar (337). pauca of course is odd, since this is his longest speech in the poem; but the word betrays Aeneas' intuition that anything he might say will be inadequate after a speech such as Dido's. The comment of Conington on the earlier use of pauca (tandem pauca refert, 333) is equally applicable to this one: " "pauca" ... seems to express Virg.'s feeling that the words come slowly and with effort, and bear no comparison to what the lover would have said had he given way to his emotion'. ${ }^{\text {I2 }}$

7 Austin (1955), 98.

8 Eur. Med. 465-519, Ap. Rhod. Argon. 4.335-90. For detailed comparisons, see, besides the commentators, Heinze (I9I5), I34 n.I and Highet (I972), 220-3.

9 Austin (1955), 98.

Io Cf. the brief remarks of Clarke (1949), 2I: 'the rhetorical system of eliciting all the arguments inherent in a situation lies behind Dido's speech in Virgil as it lies behind Ovid's letter [Her. 7]'; also 26.

II If my discussion of Dido's speeches, here and below, appears harsh, let me say that I do not consider we are ever intended to lose our sympathy for the Queen (here I cannot agree with Quinn (I963), 48-50 on a 'shift' in attitude as the book goes on). It is not a matter of 'judging', still less of deciding which 'side' we favour: cf. the sensible remarks of Douglas (I96I-2), I7, in his excellent address to the Vergilian Society: 'What Vergil has done is to present an unpartisan view of all the issues. He has told the truth.'

${ }^{\text {I2 }}$ Conington (I88I-4), 2.284. George Eliot (I967), 839 catches the sensation in a passage extensively modelled on this scene, when Daniel Deronda attempts to address the shattered Gwendolyn Harleth: 'he paused a little between his sentences, feeling a weight of anxiety on all his words'. Deronda's attempts at self-control remind one irresistibly of Aeneas: 'Deronda, too, felt a crushing pain; but imminent consequences were visible to him, and urged him to the utmost exertion of conscience' (ibid.). 
The meaning of pro re is a matter of dispute: 'the urgency of the case admits only a brief reply'; 'I shall speak only briefly, in view of the situation'; 'I will now briefly deal with the charge'; 'let me speak a few words to meet the case'. ${ }^{13}$ Austin and Page come closest to the mark. Servius (ad loc.) understood res thus, in the meaning 'a matter at issue (in a dispute, esp. in a court of law)': $:{ }^{14}$ remoto ingrati crimine descendit ad causam ('having got rid of the charge of ingratitude he gets down to the matter at issue'). Seneca took the phrase the same way, if we may judge by his imitation (which provides a parallel for the use of pro): pauca pro causa loquar/nostra ( $H F$ 4OI-2).

There is also present a very important subsidiary connotation of 'fact as opposed to words': cf. Matius to Cicero, te rogo ut rem potiorem oratione ducas ('I ask you to consider the facts more powerful than style', Cic. Fam. II.28.5 - 'the facts of Matius' present situation and past record', as Shackleton Bailey (1977) paraphrases in his commentary ad loc.); Cic. Tusc. 5.32, rem opinor spectari oportere, non uerba ('I think the fact should be considered, not words'); Quint. Inst. 3.8.32, quod nos honestum, illi uanum ... uerbis quam re probabilius uocant ('what we call honourable, they call empty ... and finer in words than in fact'). ${ }^{I 5}$ Euripides exploits a similar two-sidedness in $\pi \rho \tilde{\alpha} \gamma \mu \alpha$, when Hippolytus begins to answer the charges of his father: tò $\mu \varepsilon \dot{v}$ то $\pi \rho \tilde{\gamma} \gamma \mu^{\prime}$

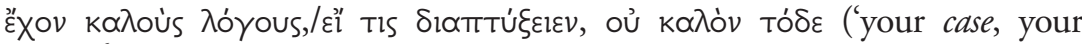
charge ${ }^{16}$ affords the opportunity for fine words, but if one should open it up, the facts of the matter are not at all fine', 984-5). In Hippolytus' speech, the $\lambda$ óyos/źpyov antithesis is explicit in the collocation of $\pi \rho \tilde{\alpha} \gamma \mu \alpha$ and $\lambda$ óyous; in Aeneas', the antithesis is more diffuse, looking forward to ne finge (338), and referring back to quae plurima fandolenumerare uales (333-4).

It has been argued ${ }^{17}$ that Aeneas is insulting Dido with these words, quae plurima fandolenumerare uales. But since Dido has in fact referred to her kindness to Aeneas only very briefly in her first speech (si bene quid de te merui, 317), it is more sensible to follow the interpretation of Servius Auctus (on 335), which refers the meaning to the future. ${ }^{\mathrm{I} 8}$ If the words

${ }^{13}$ Conington (188I-4) ad loc.; Highet (1972), 76; T.E. Page (1893), 417; and Austin (1955) ad loc., respectively.

${ }^{14}$ Oxford Latin Dictionary s.v. res IIa.

is Virgil has capitalised upon the antithesis twice in the preceding section: heu quid agat? quo nunc reginam ambire furentem/audeat adfatu? (283-4); temptaturum aditus et quae mollissima fandi/tempora, quis rebus dexter modus (293-4).

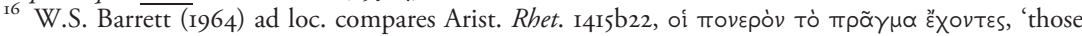

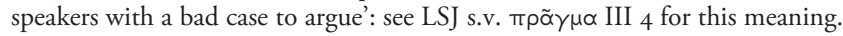

${ }^{17}$ See Pease (1935) on 333.

${ }^{18}$ quantacumque enumerare potueris in me tuo beneficio conlata, eorum tibi debere gratiam non repugno ('however great the benefits you will have been able to list as conferred on me by your kindness, I do not refuse to owe you gratitude for them'). 
refer to the future, we look to the future, and we find there, in Dido's second speech, a list of precisely the sort which Aeneas here tells her is superfluous: eiectum litore, egentem/excepi et regni demens in parte locaui./amissam classem, socios a morte reduxi ("when you were thrown out on the shore, in need, I took you in and like a fool I gave you a share in my kingdom. I brought back your fleet and your companions from death', $373-5)$.

What is the force of Aeneas' language in this clause? enumerare has aroused no comment, but it is an odd word to find in an epic. Virgil uses it once elsewhere, in its basic sense of 'numbering off, when Anchises in the underworld announces that he will 'count off his future progeny: hanc prolem cupio enumerare meorum (6.717). What Virgil intends here is quite different. He uses the word in its technical rhetorical sense of

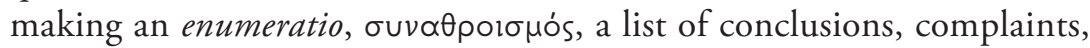
etc., which could be used in various parts of the speech. ${ }^{19}$ Apart from Virgil, the only poets who exhibit the verb in this specialised rhetorical sense are those two most 'rhetorical' poets, $\mathrm{Ovid}^{20}$ and Statius. ${ }^{2 \mathrm{I}}$ Aeneas' words are, more specifically, part of the 'long enumeration' motif, which stresses the undesirability or impossibility of making a long or complete list. $^{22}$

Aeneas here is at once conceding the value of all that she has done for him and defensively anticipating that she can make up a fine list if she wants to. But it will do no good. pro re pauca loquar is a plea for both of them to eschew a parade of words, to face the facts, to stick to the point. Of course, to Dido (and to many readers), the services she has done for him are the point, and she returns to them in her next speech (373-5), listing them over until she is mad with pain (heu furiis incensa feror!, 376), unable to believe that to Aeneas they are not everything as well.

Aeneas moves on to the two matters at issue, his 'flight' and their 'marriage': neque ego hanc abscondere furto/speraui (ne finge) fugam, nec coniugis umquam/praetendi taedas aut haec in foedera ueni ('nor did I hope to sneak away furtively in flight, nor did I ever hold forth the marriage torches of a husband or enter into these covenants', 337-9). These two and

I9 See Martin (1974), 307; for many examples of the technical use of the verb, see TLL s.v. 6I8.44ff., sensu technico rhet.

${ }^{20}$ Twice: Met. I.215; Ars Am. I.254-6, quid tibi femineos coetus uenatibus aptos/enumerem ... ?/quid referam Baias?

${ }^{21}$ Seven times: e.g. Achil. I.I40, sed longum cuncta enumerare; Silv. 3.I.IO2, uix opera enumerem.

${ }^{22}$ Cf. Nep. Lys. 2.I, ne de eodem plura enumerando defatigemus lectores; Cic. Planc. 74, omnes [gratias] enumerare nullo modo possent. 
a half lines are all he has to say on the two counts. The two items are linked; moreover, it is important to realise that the linking is not a matter of economy: they are viewed under the same aspect. The problem of the marriage was discussed above: I turn to that of the departure.

When, after Mercury's visitation, Aeneas orders his men to prepare to leave, he tells them classem aptent taciti sociosque ad litora cogant,/arma parent et quae rebus sit causa nouandis/dissimulent ('to fit out the fleet in silence and get the companions to the shore, get the equipment ready and cover up what the reason is for everything changing', 289-9I). When Dido's first sentence of attack only fourteen lines later picks up these very words (dissimulare etiam sperasti, perfide, tantum/posse nefas tacitusque mea decedere terra?, 'did you hope, traitor, to cover up such a great wrong and get away from my territory in silence?', 305-6), the correspondence is seized upon by Highet as a sure means of exposing the shabbiness which Aeneas displays when he denies that he was attempting to run away without telling her: 'to his hearer, and to nearly all readers, this must appear to be a barefaced lie'. ${ }^{23}$ Virgil, however, takes four lines (29I-4) to tell us that Aeneas fully intends to speak to the Queen before going; so that when Aeneas replies that he had not planned to run away without speaking to her, we have no option but to believe him.

The correspondence between Aeneas' words and Dido's serves to establish in the question of the departure the same ambiguity and the same atmosphere of partial justification which Virgil had set up in the question of the marriage. Dido has feared all along that Aeneas would run away from her, ${ }^{24}$ and she is now entitled to believe that it is happening, because Virgil has created a ready illusion that this is what Aeneas is in fact doing. Aeneas is deceiving her, but she does not know that he is deceiving her only for a time. ${ }^{25}$ She pounces on his actions and treats them as plain in fact and motive, with the (partial) justification for her interpretation made plain to Aeneas and the audience by her use of his very words. This is the quagmire which the poet, by a sleight of hand, reveals before his hero, as Aeneas hears his own words being, as it were, quoted back at him.

Aeneas digs his heels in and doggedly insists that she is mistaken. Faced with a tangle of right and wrong, of motive and justification, with an opponent, not an interlocutor, so single-mindedly insistent on her interpretation alone, he is

\footnotetext{
${ }^{23}$ Highet (1972), 75; cf. 289. It is surprising that, so far as I discover, Highet is the only writer on the problem to attempt to explain this striking and significant correspondence.

${ }^{24}$ Cf. 298, omnia tuta timens; 419-20, hunc ego si potui tantum sperare dolorem, /et perferre, soror, potero.

25 Nor, of course, does she know why he is going.
} 
blunt in disillusioning her. ${ }^{26}$ The terse defensiveness of his speech, so notoriously chastised by Page and others, ${ }^{27}$ corresponds to the familiar silence or strained taciturnity of more modern heroes, when faced with an uncompromising attack from wife or lover. ${ }^{28}$ Thus Vronsky before Anna, towards the end: 'And standing before her he brought out slowly: "Why do you try my patience?" He looked as if he could have said a good deal more but was holding himself in. ${ }^{29}$ Governing all these reactions is the same sense of incapacity before an insistent pressure of words.

Dido's determinedly one-sided view both of his departure and of their 'marriage' is rejected as if in one breath, for the same irresolvable problems of appearance and half-truth apply to both questions. hanc fugam and haec foedera are parallel, and some of the force of ne finge carries over into the second clause: 'this running away you speak of, those relations you speak of, they do not in reality exist: do not mould things so that it looks as if they do' (neque ego hanc abscondere furto/speraui (ne finge) fugam, nec ... haec in foedera ueni, 337-9).

With ne finge, Aeneas' criticism of her speech comes into the open. The words are perhaps weary, or even plaintive, rather than brutal, but the force of the rebuke becomes apparent in the context of Virgil's use of fingere elsewhere. The verb occurs in relation to speech in four other places. When Fama moves about Libya, she is described as tam ficti prauique tenax quam nuntia ueri ('as much an aficionado of the fictive and depraved as a messenger of the truth', 4.I88). Turnus tells off the disguised Allecto for trying to alarm him about the Trojans: ne tantos mihi finge metus ('don't invent such great fears and foist them upon me', 7.438). Finally, in the great clash of words between Drances and Turnus in Book II, each man throws the word at the other. First Drances, inuisum quem tu tibi fingis (et esselnil moror) ('I whom you misrepresent as being hostile to you - and I waste no time denying that', II.364-5). Then Turnus, uel cum se pauidum contra mea iurgia fingit,/artificis scelus ('he makes out that he is panicky in the face of

26 Though it does not seem to be recognised that when Aeneas says nec coniugis umquam/praetendi taedas ('nor did I ever hold forth the marriage torches of a husband') he is in fact admitting a grave moral failing. If a man of Aeneas' (even compromised) integrity says that he did not use promises of marriage as a pretext, he is not simply telling the woman she has nothing to complain about.

27 See, conveniently, Pease (I935), 45-6; Austin (I955), I05.

${ }^{28}$ Such is the preconception behind the bluff appraisal of Aeneas' predicament in Speaight (I958), 8: 'There are situations in which there is practically nothing a man can say.'

29 Tolstoy (I954), 776. Simone de Beauvoir (I960), 464 catches the predicament acutely, with a mother facing her daughter: 'She had a talent for jumbling the true and the false with such skill that I was overwhelmed by the effort I'd have to make to contradict her. Weakly, I said, "You've got everything all twisted."' 
my verbal assaults—a professional's trick', II. 406-7). Aeneas' use of the word is not savage as in the Turnus-Drances exchange-nor is it as indulgent as Turnus' reproach to Allecto. What Aeneas tells her is that she should not 'mould' the facts into her own view; English perhaps says 'twist'. Virgil puts into his mouth, to convey the criticism, a word that pinpoints with some precision the moulding and misrepresentation which is part of the orator's stock-in-trade: cf., e.g., Cic. Flac. 5I, tota enim conuertet atque alia finget ('he will turn everything around and make it different'). ${ }^{30}$ Hence the mutual charges of distortion and pretence that pass between Turnus and Drances; hence Aeneas' protest against Dido's use of apparent 'fact' in her presentation of her charge on the matters of the departure and the marriage. ${ }^{3 \mathrm{I}}$

Aeneas now attempts to make Dido understand the pressures upon him. The comment of R.D. Williams upon this central section is extreme, but not unrepresentative of modern views: 'His effort to minimise the pain of the situation by avoiding emotion makes his speech seem hard and unfeeling. ${ }^{32}$ This desiccation of Aeneas' words is a result of the false point of view from which his conflict is normally regarded: love for Dido on the one hand, dry duty on the other. ${ }^{33}$ Monti has sympathetically demonstrated that the issue is a clash between two 'loves': ${ }^{34}$ his obligations to his son, his men, his father's memory, his gods, these are emotional commitments, the force of which he expounds with urgency to Dido, trying to enable her to see why he must act as he does.

At the end of his exposition of the human and divine pressures upon him, Aeneas once more addresses Dido personally, saying desine meque tuis incendere teque querelis ('stop burning up yourself and me with your laments/expostulations', 360). querelis has been described as 'one of the few words in the episode that are characteristic of the erotic elegy', ${ }^{35}$ but such is not the tone here. Only once elsewhere does Virgil use the word of an articulate creature, when he puts it in the mouth of Juno, who rounds

${ }^{30}$ Further examples in TLL s.v. IIb of fingere as the hallmark of oratorical or impassioned speech.

${ }^{3 \mathrm{I}}$ For the antithesis present here between res and fingere, cf. Cic. Brut. I49, uereor ne fingi uideantur haec, ut dicantur a me quodam modo: res se tamen sic habet.

32 R.D. Williams (I97I), 423.

33 A convenient collection of the views of the consensus in Monti (I98I), IO4 n.II. Austin (I955) is aware of the emotional force of Aeneas' words at some points in this central portion: see his remarks on 35Iff. Similarly Lefèvre (I974), III-I2.

34 Monti (I98I), 42-3; cf. I04 n.IO: 'Aeneas tells Dido not only that his obligations prevent him from remaining with her, but also that he faces the choice between love for her and love for his own people and that he does not decide in her favor. This is not to deny that Aeneas loves Dido; it is a question of choices.'

35 De Witt (1907), 78. 
off her speech against Venus in Book to by pouring scorn on the other goddess' remonstrations: nunc sera querelis/haud iustis adsurgis et inrita iurgia iactas ('now too late you rise up with your unjust expostulations and hurl about pointless abuse', I0.94-5). In Juno's mouth the word carries its technical rhetorical meaning of 'expostulation' or 'protest'. Cicero gives as an example of the communes of earlier orators uitiorum et peccatorum acrem quamdam cum amplificatione incusationem aut querelam ('a certain harsh and ramped-up attack on and protest against vices and sins', De or. 3.I06); and in the Topica he lists querelae in the subheading 'practical questions relating to emotion': quo ex genere sunt querelae, incitationes, miserationesque flebiles (86). ${ }^{36}$

The rhetorical reference of querelis is brought out by the rhetorical reference of meque... incendere teque. incendere is commonly used to describe the inflammatory effect of speech, whether on a crowd or an individual, ${ }^{37}$ and Virgil has this usage often: incenditque animum dictis (4.197); talibus incensa est iunenum sententia dictis (I2.238). ${ }^{38}$ More specifically, incendere attains the status of a semi-technical term in Cicero's oratorical writings, to describe the effect of the emotional weapons of which he was so fond-hae dicendi faces, as he calls them ('these torches of oratory', De or. 2.205). The orator will use his words to set his audience ablaze with emotion. Thus Demosthenes in the De Corona, though beginning calmly, post sensim incendens iudices, ut uidit ardentis, in reliquis exultauit audacius ('next gradually setting the jury on fire, when he saw them ablaze, he vaulted more boldly in the remainder of the speech', Orat. 26). ${ }^{39}$

Aeneas' words, however, are more pointed than this: both of them are being set on fire by her remonstrations (meque ... teque). Such is the power of her words that the more she tries to set Aeneas on fire the more inflamed she herself becomes, and the more inflamed she becomes the more she tries to set him on fire. This mutual conflagration is the effect which Cicero, and after him Quintilian, ${ }^{40}$ describe as the aim of the orator who wishes to achieve the most effective pathos. No orator, says Antonius, can set his listeners alight unless he himself is on fire: ut enim nulla materies tam facilis ad exardescendum est, quae nisi admoto igni ignem concipere possit, sic nulla

${ }^{36}$ Cf. Part. or. I21, Brut. 88; in speeches, Lig. 23, Scaur. 39, Flac. 55, 87.

${ }^{37}$ Plaut. Pseud. 20I, sermone huius ira incendor; Liv. I.59.II, his ... memoratis incensam multitudinem perpulit ut...

${ }^{38}$ Cf. I.5O, talia flammato secum dea corde uolutans; II.376, talibus exarsit dictis uiolentia Turni.

39 Cf. De or. 3.23; Quint. Inst. 4.2.75, peroratio incendit et plenos irae [iudices] reliquit; ibid. II4.

${ }^{40}$ Inst. 6.2.26-8. 
mens est tam ad comprehendendam uim oratoris parata, quae possit incendi, nisi ipse inflammatus ad eam et ardens accesserit ('just as no material is so prone to bursting into flame that it can catch fire unless fire is moved up to it, so no mind is so ready to take in the force of the orator that it may be kindled unless he himself has approached it in flame himself, and ablaze', De or. 2.190). Antonius singles out Crassus as supreme here: so powerful, he says, is Crassus' repertory, ut mihi non solum tu incendere iudicem, sed ipse ardere videaris ('that you seem not only to set the judge on fire but to be ablaze yourself, I88). ${ }^{4 \mathrm{I}}$

What Aeneas is telling Dido here is that her words are a reckless incitement of passion, by which both of them are being made to suffer for no purpose: with remonstration and passionate protest alone nothing can be achieved but torture. She is, by a different metaphor, 'intoxicated' by her language. The effect he fears continues in her next speech. She uses her words to stoke her passion, until she feels herself ablaze with indignation and hurt-heu furiis incensa feror! ('alas I am carried along on fire with passion!', 376).

Aeneas' criticism here is of a piece with his criticism at the beginning of his speech. No solution or reconciliation is possible if her words are only vehicles of a one-sided offensive which, by its very nature, precludes compromise or understanding. We note, too, that his criticism is couched in specific, even technical language, which relates precisely to the use (or misuse) of language as employed by the orators: I return later to the significance of this fact.

It is impossible to tell how Virgil would have finished the speech had he lived to complete the poem. All we have is a truncated reference-the only one-to Aeneas' emotions: Italiam non sponte sequor ('I am not following after Italy of my own accord', 36I). But Aeneas is interrupted (bene 'dicentem' non 'postquam dixit', 'Virgil well says "as he spoke" not "after he spoke", Servius Auctus on 362$)^{42}$ by a Dido who expresses only contempt for his explanations: scilicet is superis labor est ... etc. ('oh sure, this is something the gods are taking trouble over', 379). Of his father, his son, his people, she makes no mention. Her second speech (362-87)

${ }^{4}$ Speaking of his own prowess in the Orator, Cicero claims nulla me ingeni sed magna uis animi inflammat, ut me ipse non teneam; nec umquam is qui audiret incenderetur, nisi ardens ad eum perueniret oratio ("no great force of intelligence inflames me, but rather that of spirit, to the extent that I can't restrain myself; nor would the listener be inflamed, unless the speech came to him on fire', I32).

42 Whenever Virgil has dicens $(2.550$; I0.744, 856; I2.950) or dicente (IO.IOI), he means 'even as X spoke'. 
abandons any attempt at persuasion, and develops passionately the attack which had formed only part of her first speech. ${ }^{43}$

She interrupts herself by fleeing his presence (388-90). And he is left, multa metu cunctantem et multa uolentem/dicere ('hesitating in fear over many things and wanting to say many things', 390-I). After the gulf that has opened between them, the enjambment and isolation of dicere harshly expose the inadequacy of mere speech. Thus was Orpheus left standing by his wife, prensantem nequiquam umbras et multa uolentem/dicere ('grabbing at the shades in vain and wanting to say many things', G. 4.500-I); thus, more appositely, was Aeneas left by the shade of his wife Creusa in Book 2, lacrimantem et multa uolentem/dicere deseruit ('she left him in tears and wanting to say many things', 790-I). The comfort he wishes to give Dido he cannot provide (393-6): any hope of solace or reconciliation is denied.

\section{II}

If we look at this block of speeches with our attention centred on the character Aeneas, two points stand out. First, the distinction, patent in the speeches themselves and picked out by Aeneas, between Dido's use of speech and Aeneas'. Second, the ineffective and unnaturally truncated nature of the dialogue, with the denial to Aeneas of the opportunity to speak the words he wishes to speak.

We saw that Virgil marks the breaking-off of the dialogue with words that recall Aeneas' enforced silence in Book 2, when the shade of his wife vanishes before he can reply to the speech it has delivered. With his mother Venus the same frustration of speech is to be observed. Near the beginning of Book I Aeneas has a long and important conversation containing much information and instruction (32I-4OI); but he does not know he is speaking with his mother, for she is in disguise. As she turns away he recognises her; he follows while she flees from him (fugientem, 406), calling out, cur dextrae iungere dextram/non datur ac ueras audire et reddere noces? ('why is it not granted to join right hand to right hand and to hear and exchange genuine conversation?', 408-9). Their conversation has not in fact been genuine, and contact between them is deliberately broken off by the mother before the son may speak and hear ueras uoces. 'The distance between god and man remains irremoveable, even between mother and son', remarks A. Wlosok on the passage, with a degree of truth; ${ }^{44}$ but it is

\footnotetext{
${ }^{43}$ My description of this second speech is only a precis of R.D. Williams (I97I).
}

44 Wlosok (1967), 87. 
not simply because Venus is divine that Virgil has represented her as inaccessible to her son's speech. ${ }^{45}$ Aeneas also suffers one such broken exchange with his father, at the end of Book 5 (722-42), when Anchises' shade flees at the approach of dawn. iamque uale, says Anchises ('and now farewell', 738): the same phrase in the same position is spoken to Aeneas by Creusa's ghost (2.789). ${ }^{46}$ Aeneas speaks as the shade vanishes, quo deinde ruis? quo proripis? ... Iquem fugis? aut quis te nostris complexibus arcet? ('where are you rushing to so soon? To where are you snatching yourself away? Whom are you fleeing? Or who keeps you away from my embraces?', 74I-2). As the silent shade of Dido turns away from him, Aeneas likewise calls out, quem fugis? ('whom are you fleeing?', 6.466); he follows his mother as she runs away from him, fugientem ('fleeing', I.406).

These episodes are examples of a feature of the Aeneid which has often been commented upon, namely, the poem's small share of dialogue or conversation. Heinze chose this observation as the starting point for his discussion of the speeches, taking Homer as the standard of comparison; ${ }^{47}$ Highet provides statistics, with some further discussion. ${ }^{8}$ Some picture of the Homeric model is necessary in order to establish the background. ${ }^{49}$ The aspect I wish to concentrate on is the efficacy, the potency of Homeric speech and dialogue, the way in which speech is used by Homer's men and women to approach each other, to attain an end, to achieve a solution.

The councils of the Achaean chiefs in the Iliad reveal progress and development as the words spoken work their way upon the minds of the hearers. Book 9 has two fine examples. At the beginning of the book there is a lengthy debate, in which we hear speeches from Agamemnon, Diomedes, Nestor, Agamemnon, and finally Nestor again. Agamemnon had at first been in despair, suggesting that they all go home to Greece (13-28); as one speech follows another, the men move away from this disastrous proposal and eventually arrive at a solution: ambassadors will go and plead with Achilles to abandon his wrath and be reconciled. The ambassadors do not succeed in their aim, but the various effects of their various styles of oratory work progressively upon Achilles, turning him to modify his stand. ${ }^{50}$ At first he is threatening to sail home the next day

45 Further discussion of the lack of intimacy between Aeneas and Venus in Highet (1972), 37-8.

46 And to Orpheus by Eurydice's ghost (G. 4.497). $\quad 47$ Heinze (I9I5), 404.

$4^{8}$ Highet (1972), 22-5.

49 I might dispense with this section if there were an appropriate discussion to which I could refer; but I do not know of one. Indeed, there is surprisingly little written on the subject altogether, as Latacz (1975), 395 remarks in the introduction to his useful survey on direct speech in Homer.

so The modification of Achilles' position is well traced by Whitman (I958), I90; cf. Lesky (I968), 790-I. 
(356-63). After Phoenix's long speech (434-605) he relents so far as to say that he will decide on the next day whether to sail home or not (618-19). But it is the blunt rebuke of Ajax which crowns the weakening process (624-42), for his words prompt instinctive agreement from Achilles:

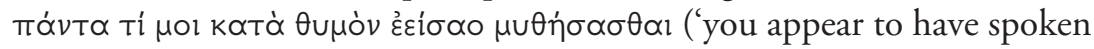
entirely in accordance with my mind', 645). All thought of leaving is now gone, and Achilles will fight if Hector comes to the ships of the Myrmidons (650-5).

The most accomplished exponent of speech in the Homeric poems is, of course, Odysseus, who is kept alive by his wits and tongue in his wanderings, ${ }^{5 \mathrm{I}}$ talking his way home through a world which is 'menacing ... with the mysteriousness of undeclared motives, inscrutable people, liars and cheats', ${ }^{52}$ and, once he is arrived, talking his way into a position where he can kill his enemies and regain his standing. The use of words between Odysseus and Penelope in their reunion scene $(23.85-240)$ has been well described by Stanford, who traces the modulation of their reactions as they speak to each other, feeling their way until recognition and reconciliation are achieved..$^{53}$ Twenty years of separation still divide them, and Athene gives them a double

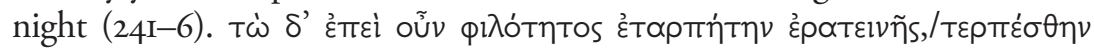

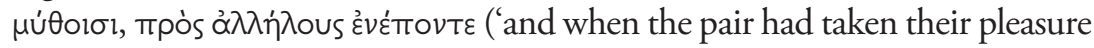
in delightful love-making, they took pleasure in words, conversing with each other', 300-I); as they speak to each other, sharing what each has suffered alone, their reunion is made complete: husband and wife reestablish their intimacy and heal their private hurt.

The healing and unifying power of dialogue is a constant feature of the Homeric poems. In Odyssey 4, for example, we see Menelaus greeting Telemachus and Peisistratus, the son of Nestor. In speaking of his lost friends, Menelaus mentions Odysseus, so that Telemachus is moved to tears (II3-I6). Helen enters and guesses his identity (I4I-4), so that first Peisistratus may openly speak of Telemachus' troubles (I56-67), and then Menelaus may speak again of his own grief for his old friend (169-82). Their words bring the purging tears to all four (183-7); Peisistratus is moved to commemorate his brother Antilochus (190-202), and Menelaus graciously puts the seal on their weeping (2I2). Their open talk of their pain, and the resulting tears which they shed together, provide some measure of solace.

The Odyssean scene is a more humble statement of the theme which dominates the last book of the Iliad. ${ }^{54}$ The gods have ordered Achilles to

\footnotetext{
51 Walcot (I977); Stanford (I963), I3-I5. $\quad 52$ Griffin (1980), 80. $\quad{ }^{53}$ Stanford (1963), 56-9.
}

54 Griffin (1980), 69. 
surrender Hector's body, and he has said that he will give it to any Trojan who may come (134-40). The arrival of Priam himself is completely unexpected, and stuns Achilles and his friends (480-4). Achilles' reaction is left in suspense, and the factor that determines his response is, quite simply, Priam's speech. Priam establishes between them the strongest link there can be, by reminding Achilles of his own father (486-506). They weep together, Priam for Hector, Achilles for Patroclus and for his father Peleus (509-I2). Griffin's comment on this scene is characteristically just: 'as the great enemies ... meet and weep together, we see the community of suffering which links all men'.55 So from the audience's point of view. For the two men, the 'community of suffering' is not an awareness that comes spontaneously upon them; it is a truth established by the words of Priam, a truth recognised and acknowledged by Achilles when he too compares the lot of his father with that of Priam (534-48), thus putting into new perspective the pity for his father which has been a cloud on his mind ever since he accepted the inevitability of his own early death. ${ }^{56}$

The link established is still fragile. Priam overplays his hand when he asks for the exchange to be made immediately, and provokes an angry outburst from Achilles (560-70); but it is Achilles who makes the next overture, by inviting Priam to eat and drink (599-620). After the meal, in a famous scene, they look at and admire each other (628-32). Priam marvels at Achilles, ö $\sigma \sigma o s$ हैทv oĩós $\tau \varepsilon$ ('at how big he was, and what he was like', 630); it passes oddly unremarked that the marvelling on Achilles'

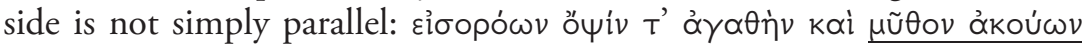
('seeing his goodly appearance and listening to his words', 632). Achilles marvels at Priam's power of speech: this is his ảpetท', his 'excellence'. ${ }^{57}$

In this way does Homer portray the palliation of a grief apparently beyond resource. The shared tears and the shared meal represent to us the stages in their reconciliation; but the reconciliation is made possible by the power of speech to draw men together and establish connections between them. ${ }^{58}$

55 Ibid., 69. ${ }^{56}$ Cf. Il. I8.330-I; I9.334-7; 23. I44-5I.

57 The allusion to Priam's speech must, as Macleod (1982) puts it in his commentary, refer to things said while they ate; it cannot refer to the moment, because as they look at each other they are silent. This is plain from the lines immediately following: 'when they had had their fill of looking at each other, then god-like Priam was the first one to speak' (632-4).

58 The observation of Griffin (1980), 69 n.36 is too bleak: 'No Egyptian drug can obliterate the sufferings of the Iliad, for which there is no alleviation and the gods can only recommend endurance.' Men can do better than this in the Iliad, even if their sufferings are not 'obliterated'. Contrast Priam's mad grief before the reconciliation scene (24.I62-5) with his self-possession afterwards (7I3-I7; 777-8I), a self-possession which is itself in strong contrast with the unrestrained passion of the mourning women. 
It is a shock to return to the Aeneid after the world of Homer. ${ }^{59}$ 'In the Homeric poems it is unusual for one character to address another without receiving a spoken reply, and conversations in which three or four people join are common. In Vergil, the reverse ... [O]f the 333 speeches in the Aeneid, 135 are single utterances which receive no reply in words. ${ }^{, 60}$ Heinze's discussion of Virgil's restrictions is still very valuable, especially on the subjects of Virgil's concern for compression and narrative pace; ${ }^{61}$ but a more thorough-going curtailment is at work. The world of the Aeneid is lacking in the Homeric style of open, cooperative and sustaining speech. Virgil consistently excludes from his poem the intimacy, companionship and shared suffering which Homer's men and women hold out to each other through speech.

In Book 3, for example, Aeneas arrives at Buthrotum in Epirus, where he finds Andromache mourning Hector on the shore. We think of such scenes as that from Odyssey 4 where shared memory and tears brought some relief to the bereaved and isolated. Such a solution is not to be looked for in Virgil. Andromache's tears are in vain (incassum, 345). Aeneas makes no reply to her long speech, nor to all the questions she asks him (337-43), since Helenus arrives and leads him off $(345-8)$. We are not told what happens to Andromache, whether she follows, or whether she stays, weeping by the tumulus of Hector where Aeneas found her. When the Trojans leave, her obsessive misery is precisely the same as when they arrived (486-9I). ${ }^{62}$

The Aeneid is rigidly undomestic. We hear no human conversation between husband and wife, ${ }^{63}$ father and son, ${ }^{64}$ mother and child. ${ }^{65}$ Viewed as a tableau, the single 'homely' scene in the poem is the sinister

59 In attempting to put Virgil's speeches in perspective, I am afraid I may have put Homer's speeches out of perspective. There is certainly unsuccessful speech in Homer; the first exchanges of words in the Iliad are disasters. But it is Homer's norm which is important (if I may borrow the terminology of Johnson (1976), chapter II).

60 Highet (1972), 23-4. Of these 135, as Highet notes, eight are soliloquies, and there are a few more deductions to be made.

6r Heinze (I9I5), 405-8.

${ }^{62}$ Cf. Grimm (1967). Grimm analyses well the lack of contact between the two, although I cannot accept his conclusions.

${ }^{63}$ No speech between Helenus and Andromache in Book 3. Amata speaks once to Latinus (7.359-72), but he does not answer; at I2.IO-80 Latinus and Amata are both present, with Turnus and Lavinia, but do not address each other.

64 Aeneas and Anchises only converse in the underworld. Evander speaks once to his son alive (dum te, care puer, mea sola et sera uoluptas,/complexu teneo ... etc., 8.58I-2), and once to his corpse (II.I52-3). Pallas never speaks to his father.

${ }_{65}$ Apart from the 'unreal' conversation between Aeneas and the disguised goddess in Book I (32I-4OI). At 8.6I2-I4 she speaks briefly to Aeneas, but he makes no reply. 
moment when Ascanius/Cupid hangs in an embrace from his 'father's' neck, and then goes to sit in Dido's lap and infect her with love (I.715-22). The gods, to whom everything is easy, are a foil. The delightful scene between Venus and Vulcan in Book 8 (370-406), with the homely simile following (407-15), is unimaginable in the human action. Jupiter and Juno reach a reconciliation in Book I2 (79I-842) in a way that no human characters do. Virgil has pruned back Homer's gods, but there remains a freeness and domesticity in the scenes in heaven (e.g. I.227-60; 4.90-I28) which is never seen on earth. W.R. Johnson is right to stress the importance in the poem of 'the rarity of conversations and debates between the actors (which ease the sense of isolated anxiety, bad solitude, which is a Vergilian hallmark) ${ }^{66}$ The most intense expression of this anxious solitude is Dido's dream (4.465-8):

$$
\text { agit ipse furentem }
$$

in somnis ferus Aeneas, semperque relinqui sola sibi, semper longam incomitata uidetur ire uiam et Tyrios deserta quaerere terra.

He himself, bestial Aeneas, harries her in her frenzy in sleep, and she seems to herself to be always left alone, always going on a long path without her entourage, looking for her Tyrians in a deserted landscape.

From the beginning to the end of the poem Virgil keeps the character of Aeneas before our eyes as the principal exemplar of this unhomeric isolation. His lack of contact with mother and wife has already been noted. ${ }^{67} \mathrm{Of}$ his affair with Dido only the formal beginning and the wretched ending are represented. ${ }^{6}$ We hear no conversation between Aeneas and his father Anchises, at least while Anchises is alive and upon the earth. In Book 2 there are four unconnected utterances between father and son: ${ }^{69}$ from Aeneas, an outburst of angry grief when his father refuses to be carried from home (657-70), and an instruction to pick up the household gods and mount on his back (707-20); from Anchises, a line of acquiescence (704), and a line and a half of panic as the pair make their way out of the city (753-4). More remarkably, during the course of Book 3, when father

66 Johnson (1976), 179. See also Lieberg (1971).

67 Earlier in Book 2, when Aeneas and Creusa are together in Anchises' house, she speaks once to him, without receiving a reply $(657-8)$.

${ }^{68}$ Highet (1972), 35: '[Aeneas] is never heard saying any special words of love to Dido, as Paris does to Helen (Il. 3.438-46); nor is he ever seen embracing her, like Odysseus with Penelope (Od. 23.23I-40).'

69 'Nicht Rede und Gegenrede' ('not speech and reply'), says Heinze (I9I5), 4IO, of the bursts of speech in Anchises' house. 
and son cooperate in steering the Trojans' fortunes, Virgil does not once show us Aeneas addressing his father, ${ }^{70}$ while Anchises speaks to his son on one occasion only, seven lines acknowledging the Penates' instructions to Aeneas to make for Italy (182-8). In the underworld there is the form of a conversation, but there is something more than disquieting about the fact that Virgil allows his hero such indulgence only in this unreal place. Even here, although Anchises has held forth the hope notas audire et reddere uoces ('to hear and exchange familiar conversation', 6.689), the conversation between them is strangely formal and unintimate; Aeneas' questions are a naturalistic way of directing and organising Anchises' exposition. ${ }^{7 \mathrm{I}}$

To his son Ascanius, heir of all his hopes ${ }^{72}$ and companion throughout his travels, ${ }^{73}$ Aeneas speaks once only: disce, puer, uirtutem ex me uerumque laborem, Ifortunam ex aliis ... etc. ('learn, boy, manly virtue from me and true hard work, good luck from others', I2.435-40). This single address is a farewell, and it has the adumbrations of being a final farewell. Its models are Hector's prayer for Astyanax (Il. 6.476-8I) and Ajax's words to his son. ${ }^{74}$ In each of these models the father never sees his son again, although Hector only suspects this fact (cf. 6.448-9), while Ajax is determined upon it. $^{75}$ Ascanius, in his turn, never speaks to his father in the course of the poem.

If Aeneas' only words to his son are in the guise of a final farewell, his only words to Pallas, his 'Patroclus', are such in fact. As the Trojans arrive at Pallanteum, Pallas rushes to interrogate them (8.IIO-I4). Aeneas does not know him when he replies, Troiugenas ac tela uides inimica Latinis ('It is Trojans you see, and weapons hostile to the Latins', II7); he goes on to speak in the plural, ferte haec et dicite ... etc. ('take these things and say ...', III). Pallas welcomes him, and takes his right hand (I22-4), but Aeneas makes no reply. From that moment until Pallas is killed, Aeneas does not address him; it is only to his corpse that Virgil represents him speaking, in a lament (II.42-58), and a short farewell: 'salue aeternum mihi, maxime Palla,/aeternumque uale'. nec plura effatus ad altos/tendebat muros ("'hail for ever, mighty Pallas, and for ever farewell". Saying no more he made his way to the high walls', II.96-8). His terseness at such crises is most poignant, as are his

70 One line of reported speech, pared and bald: Anchisen facio certum remque ordine pando (3.179).

${ }^{71}$ Cf. the introductory remarks of Austin (I977) on 6.679-702; Highet (I972), 34. Lieberg (I97I), I89, has some good comments on the emptiness of contact between Aeneas and Anchises at this point.

72 See esp. I.646; 4.234, 274-6, 354-5; I2.436-7.

73 Except for Books 8 and 9, when Aeneas is at Pallanteum without Ascanius.

74 Soph. Aj. 550-I, or Accius, Armorum iudicium, fr. Io Ribbeck.

75 This is so even if we accept the relocation of Ajax's speech in Accius, as suggested by Jocelyn (I965), I28. 
appalled and resourceless silences before scenes of great pity or terror $(3.47-8$, at Polydorus' tumulus; 6.33I-2, seeing the souls of the unburied), or his strange reticence when we expect speech from him (8.617-19, 729-3I, looking at his shield).

Aeneas is distant from his men also. ${ }^{76} \mathrm{He}$ moves in solitude through a world which yields him no intimacy or comfort, which progressively severs his ties with those who are close to him, and to whom he wishes to be close. ${ }^{77}$ His conversations are stifled, unconsummated. Here he is at his most unhomeric, particularly in Book 3, when he is following in the footsteps of his voluble Greek predecessor, Odysseus, conspicuously failing to engage in the whole range of discourse of which the more versatile hero is master. But even if Aeneas is cut off from the converse which enriches and supports the human life of the Homeric poems, much of his speech is effective, although not reciprocal or personal. He offers prayer to win the goodwill of the gods for the common enterprise, ${ }^{78}$ and confidently interprets the signs they send (e.g., 7.120-34, 8.532-40). He encourages his men after disaster (I.198-207), and orders them to decisive action. He is shown at the moment of decision ordering Anchises to get on his back and to pick up the household goods, telling his famuli to follow on (2.707-20). We hear him inaugurate the funeral games of his father, in a long ${ }^{79}$ and formal oration which is the first stage in reestablishing the group's confidence and trust, weakened by the sojourn in Carthage (5.45-7I). ${ }^{80} \mathrm{He}$ orders his army to the crucial step of marching on the city of Latinus, speaking in the harsh and authentic tone of the Roman commander (I2.565-73). He speaks as the representative of his people in diplomacy, most notably when he seals the vital alliance with Evander (8.127-5I). ${ }^{8 \mathrm{I}} \mathrm{He}$ does not make the initial alliance with Latinus in Book 7; one of the many reasons for this is that the alliance is broken, and whenever Aeneas makes a diplomatic arrangement it sticks (with the disastrous exception of his pact with Dido in Book $\mathrm{I}$ ): note his promise of friendship with the descendants of Helenus (3.500-5), and the ties he establishes as he founds the city for Acestes (5.749-6I).

The effectiveness of Aeneas' public speech, either civil or military, is put into perspective when seen beside the speech of the other characters in the

\footnotetext{
${ }^{76}$ Highet (1972), 4I-2.

77 On Aeneas' solitude, see Lieberg (I97I), I76-9; Elftmann (1979); especially Liebing (1953), 22, 95, IIO, I52.

${ }^{78}$ Highet (1972), 39. $\quad{ }^{79}$ The second longest he makes.

${ }^{80}$ Cf. Quinn (1963), 48: 'One of the functions of Book V is to heal this alienation of commander from his men.'

${ }^{8 \mathrm{I}}$ His third longest speech in the poem.
} 
poem. We look in vain in the Aeneid for examples of the Homeric type of many-sided debates leading to a worthwhile result. On the few occasions in the Aeneid when more than four speeches from three or more speakers come together in a cluster, the atmosphere is panic-ridden and hysterical. The 'Homeric' consultation scene in Book 9, with speeches from Nisus, Aletes, Ascanius, Euryalus and Ascanius again (234-302), is an undisciplined and excited shambles, which issues in disaster: Aeneas, of course, is absent from his army. The set-piece debate in the Latin Senate in Book II is a mere shouting match; Latinus' proposals for peace are buried in the exchange of words between Drances and Turnus (225-46I). The bedlam is shown for what it is by an interruption: illi haec inter se dubiis de rebus agebant/certantes: castra Aeneas aciemque mouebat ('they were carrying on like this among themselves, wrangling over uncertain matters: Aeneas was moving his camp and his battle-line', 445-6). As they tussle away Aeneas acts. ${ }^{82}$ Perhaps here lies some part of the explanation for the avoidance of conversation between Aeneas and Anchises in Book 3. Virgil may have been afraid that, by representing constant consultation instead of implying it, he would produce an impression, not of harmony, but of dither. Such an impression would undermine the image he wanted of an effective leadership, as opposed to the disorder of unstructured debate.

A more profound distinction is that which we saw at work in the private sphere, in the opposed speeches of Aeneas and Dido. Speech is not available as a palliative or a private bond in the Aeneid: worse, men and women use speech against each other and against their own interests, deceiving or bludgeoning with words to produce disastrous results. The most spectacular example is Sinon's speech in Book $2{ }^{83}$ but virtually all the major emotional speeches of persuasion or coercion contain falsehood and misrepresentation, generate and are generated by passion, and lead to calamity: so the speeches of Amata in Book 7 (359-72), Turnus and Drances in Book II (343-444), and Tolumnius in Book I2 (259-65). ${ }^{84}$ Highet's conclusion is substantially correct: 'Vergil, it seems, held that powerful oratory was incompatible with pure truth, and that every speaker presented his or her own case by misrepresenting the facts. ${ }^{85}$

${ }^{82}$ A similar perfervid atmosphere prevails at the beginning of Book 12 ( $10-80$ ), when we hear speeches from Turnus, Latinus, Turnus, Amata, Turnus. The appeals of Latinus and Amata, so far from inducing Turnus to give up the war, drive him into an even greater frenzy.

${ }^{83}$ talibus insidiis periurique arte Sinonis/credita res, captique dolis lacrimisque coactis/quos neque Tydides nec Larisaeus Achilles, Inon anni domuere decem, non mille carinae (2.195-8).

${ }^{84}$ See Heinze (I9I5), 42I-4; Highet (1972), 285-90. On Anna's speech in Book 4 (3I-53), see G.S. West (I979), IO-I3.

85 Highet (1972), 289. 
It is as well to be precise about this, for there is little profit in bandying about the word 'rhetorical' as an indiscriminate term of abuse. Much of Highet's discussion is vitiated by the stance he adopts on the Vergilius poeta an orator question, ${ }^{86}$ a stance which is little more than 'poetry good, rhetoric bad'. Rhetorical elements in the organisation of the speeches in the Aeneid are simply an observable fact, ${ }^{87}$ and if we describe any particular speech as 'rhetorical' we do not commit ourselves to a necessary value judgement. What does emerge from the Aeneid is a mistrust of powerful language that divides into two aspects, corresponding to the two heads under which Aeneas criticises Dido's speech: powerful language distorts reality, or the truth, in its singleminded pursuit of its particular aim; and it exploits ungovernably the emotions of speaker and audience. The power of words in a private and a public context is thus suspect in analogous ways.

The rhetoricians themselves were fully alive to the force of such criticisms (Quint. Inst. 2.I6.I-2):

quidam uehementer in eam [rhetoricam] inuehi solent ... : eloquentiam esse quae poenis eripiat scelestos, cuius fraude damnentur interim boni, consilia ducantur in peius, nec seditiones modo turbaeque populares sed bella etiam inexpiabilia excitentur, cuius denique tum maximus sit usus cum pro falsis contra ueritatem ualet. ${ }^{88}$

Some habitually make strong attacks against rhetoric, saying that it is speech which saves the wicked from punishment, and that by its deception good men are sometimes condemned, deliberations are led in the wrong direction, and not only popular seditions and riots but also irremediable wars are roused, and finally that its use is greatest when it prevails for falsehood against truth.

But when they are praising high-powered oratory, and giving advice on its use, the oratorical writers are almost disarmingly candid about their aims and methods:

ubi uero animis iudicum uis adferenda est et ab ipsa ueri contemplatione abducenda mens, ibi proprium oratoris opus est ... sicut amantes de forma iudicare non possunt quia sensum oculorum praecipit animus, ita omnem ueritatis inquirendae rationem iudex omittit occupatus adfectibus.

But when force is to be applied to the minds of the jury, and when their mind must be distracted from the bare contemplation of the truth, that is the proper task of the orator ... Just as lovers are no judges of beauty because excitement removes their power of sight, so a juryman leaves behind every

${ }^{86}$ Ibid., 277-90. ${ }^{87}$ See G.A. Kennedy (1972), 390-2; Russell (I98I), I26-8.

88 These words should be read with Aeneid 7, II and I2 in mind. 
mode of inquiring into the truth when seized with emotion. (Quint. Inst. 6.2.5-6)

nihil est enim in dicendo ... maius, quam ut faueat oratori is, qui audiet, utque ipse sic moueatur, ut impetu quodam animi et perturbatione, magis quam iudicio aut consilio regatur. plura enim multo homines iudicant odio aut amore aut cupiditate aut iracundia aut dolore aut laetitia aut spe aut timore aut errore aut aliqua permotione mentis, quam ueritate aut praescripto aut iuris norma aliqua aut iudicii formula aut legibus.

Nothing is more important in oratory than that the listener should sympathise with the speaker, and be moved himself in such a way that he is ruled by mental excitement and disturbance rather than by prudence and judgement. For men make judgements in more cases through hate, love, desire, anger, joy, hope, fear, error, or some excitement of the mind, than through truth or prescription or any rule of the court, or formula of judgement, or laws. (Cic. De or. 2.178)

illud autem genus orationis [sc. uehemens] non cognitionem iudicis, sed magis perturbationem requirit.

That [powerful] type of oratory does not have as its target the judging capacity of a juryman, but rather his disturbance. (Cic. De or. 2. 2I4)

High rhetoric does not admit of dubiety: it is concerned in the first and last resort, not with any objective establishment of a truth, but with getting its way; and it gets its way by whirling speaker and audience up in a grip of passion in which judgement and discrimination are deliberately expunged, in which partial justification, half-truth, uncertainty are nothing but irrelevancies. Criticisms of such language as an evil have a long history, of which the Aeneid is a part. ${ }^{89}$

Aeneas stands out prominently against this background. He does not lie when he speaks: ${ }^{90}$ often he speaks with great emotion, but he does not use words to win his way by overpowering one emotion with another. The lassitude which so many readers sense in Aeneas' speeches ${ }^{91}$ is in fact

89 See von Arnim (I898), 4-II4 ('Sophistik, Rhetorik, Philosophie in ihrem Kampf um die Jugendbildung'); Vicaire (1960), 276-80; G.A. Kennedy (1963), I4-I7; Hellwig (1973), 304-7.

90 Despite the claims of Highet (I972), 287-9 that Aeneas distorts the truth like other speakers. His examples are ill founded. At, e.g., I.200-I, Aeneas tells his men uos et Scyllaeam rabiem penitusque sonantis/accestis scopulos. 'Aeneas speaks as though he and his men had actually braved the dangers of Scylla and Charybdis, whereas the narrative shows that they avoided them by sailing southward along the Sicilian coast...' (Highet (1972), 288). Aeneas in fact tells his men that they went close to Scylla and Charybdis (accestis, I.2OI), and this is precisely what happened: laeuam cuncta cohors remis uentisque petiuit./tollimur in caelum curuato gurgite, et idem/subducta ad Manis imos desedimus unda (3. 563-5.).

${ }^{91}$ E.g. 5.45-7I, 8.I27-5I, II.IO8-I9. 
a restrained disavowal of the fervour which animates the language of the other characters when they seek to influence their listeners. The restraint tightens progressively into terseness as the tension of the last third of the poem increases, as Aeneas' role is restricted to the business of leading armies and killing Latins. ${ }^{92}$

We are left with a discrepancy, blunt but not distorting, between Aeneas' private and public speech. In the private realm, he is the poem's most consistent and prominent paradigm of the weak and insubstantial nature of human interchange; in the public realm, he is increasingly successful through the course of the poem as the leader of the Trojan enterprise, whether as diplomat or general, with exhortation, encouragement and direction, free from the manipulation and distortion which controls the words of the other outstanding orators of the poem. Highet sketched out the right area for an understanding of the problem when he attempted to refer it to Virgil's observation of Augustus, but his analysis is rather confused..$^{93} \mathrm{~A}$ more satisfying discussion is that of D.J. Stewart, who writes with the assumption that 'one of the tasks ... Virgil set for himself in the Aeneid was to write literature about institutions and the political vocation'. ${ }^{94} \mathrm{He}$ catches well, though one might quarrel with some of his expression, the truth about Aeneas' position:

All those flat, dull speeches of encouragement, all that weariness, that general hangover quality which Aeneas both experiences and communicates when he looks out over the world, are the politician's special burden. He must pretend to enthusiasms he does not feel, repress emotions he does feel, and generally behave not as a free individual but as the incorporation of a society's needs, a trust-officer for other people's future. ${ }^{95}$

Again, on Dido: 'The Dido story is a metaphor for what any politician must be prepared to do: to sacrifice every last personal tie, if necessary, to help keep the political enterprise going. ${ }^{96}$ The same design guides the denial to Aeneas of free interchange with all those closest to him.

92 See Highet (1972), 39-40.

93 He concludes: 'For Vergil both Augustus and his prototype Aeneas were more godlike than human; and a god, as we know from Aristotle, cannot have human friends' (Highet (1972), 43). But his consequent remarks are more valuable: 'Did he not also wish to show him as one who, after almost unendurable losses and sufferings, had grown into the melancholy of middle age and the grave contemplation of approaching death?' (ibid.). [For my later retraction of this uncomprehending criticism, see Vol. I.6, n.6o.]

94 D.J. Stewart (1972-3), 650.

95 Ibid., 659-60. A fine example is the worthy but flat oration with which Aeneas inaugurates the funeral games (5.45-7I); this is the ancient equivalent of the cabinet minister's speech at the opening of a bridge or factory.

96 D.J. Stewart (1972-3), 660. 
It is not a matter of Virgil looking at Augustus and writing down what he saw. Here is Highet's baulk, for, as he says, 'Augustus was far more sociable and less lonely then Aeneas. ${ }^{.97}$ When we consider Aeneas, aloof, repressed in speech, devoid of close friends, the public servant without control over his own destiny and attachments, it is not Augustus who comes to mind: it is Tiberius. What other Julio-Claudian could have spoken with more feeling the words of Aeneas, me si fata meis paterentur ducere uitam/auspiciis et sponte mea componere curas ... ('if the fates allowed me to lead my life under my own command and to organise my cares of my own accord', 4.340-I)? Douglas was not being facetious when he compared Aeneas' last sight of Dido (prosequitur lacrimis longe et miseratur euntem, 'he follows after her with tears and takes pity on her from a distance as she goes', 6.476) with Suetonius' melancholy description of Tiberius' last encounter with the wife Augustus had forced him to divorce: ${ }^{98}$ sed Agrippinam et abegisse post diuortium doluit, et semel omnino ex occursu uisam adeo contentis et [t] umentibus oculis prosecutus est, ut custoditum sit ne umquam in conspectum ei posthac ueniret ('but after their divorce he grieved that he had driven Agrippina away, and on the one occasion when he happened to see her as a result of a chance encounter he followed her with such strained and swollen eyes that precautions were taken that she should never thereafter come into his sight', Tib. 7.3). ${ }^{99}$

I am not suggesting that Virgil was attempting to foresee events; ${ }^{\mathrm{I} 00}$ nor was he looking back, as McKay argues when he proposes Julius Caesar as the model for Aeneas. ${ }^{\text {IOI }}$ Aeneas is not a portrait of Augustus or of any other individual. He represents generally the extreme case of the pressures and cruelties inflicted upon the individual who embodies in his own person the aspirations and future of a whole nation. ${ }^{\mathrm{IO2}}$ Augustus was the only man Virgil knew who was such a 'man of destiny'; while it is impossible to believe that Augustus was not a major influence on Virgil's conception of his hero, it is likewise impossible to make any precise suggestions as to the

97 Highet (1972), 42. One suspects that it was the early part of Augustus' Principate, when Virgil knew him, that provided the material for the conventional assessment of his comitas (Suet. Aug. 53.2-3; 66.I-3; 74). Virgil did not see the Augustus who lived through the deaths of all his early friends, and of Gaius and Lucius, who saw the disgrace of daughter and granddaughter, and survived into 'the atmosphere of gloom and repression that clouded the last decade of the reign' (Syme (I978), 205).

${ }^{8}$ Douglas (196I-2), 2I. 99 Following Ihm's Teubner text for [t]umentibus.

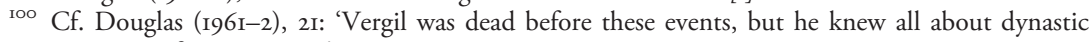
marriages of convenience.'

Iог McKay (1963).

${ }^{102}$ Cf. D.J. Stewart (1972-3), 65I: 'The Aeneid is a study of the preternatural strains and anxieties a political vocation brings to mere natural man.' 
nature of that influence. ${ }^{\mathrm{IO}}$ The character of Aeneas stands essentially in its own right, the representative of a predicament which his creator did not see as unique.

As Stewart observes, in the passage quoted above, '[ $\mathrm{t}$ ]he Dido story is a metaphor for what any politician must be prepared to do'. ${ }^{\text {IO4 }}$ It is in his confrontation with Dido that the tensions inherent in Aeneas' role become most acute. In Dido he faces the most impassioned and eloquent speaker in the poem. He feels the justice and the injustice of her speech, but he does not answer her in the same tenor. With hard-won self-control he tells her that the way she uses words is profitless and cruel, and he attempts to give an explanation, to reach some understanding. His words do not achieve their aim: but there is nothing in the poem to give us reason to believe that any other words would have been more effective.

I03 But I cannot resist quoting the following passage from Suetonius, to which Prof. Nisbet referred me as being illustrative of Augustus' constrained and inhibited use of speech: sermones quoque cum singulis atque etiam cum Livia sua grauiores non nisi scriptos et e libello habebat, ne plus minusue loqueretur ex tempore ('He did not conduct his more important conversations with individuals and even with his wife Livia unless he had them written down, from a notebook, so that he wouldn't say too much or too little off the cuff,' Aug. 84. 2).

I04 D.J. Stewart (I972-3), 660. 